\title{
Pemanfaatan Cendawan Beauveria bassiana dalam Mengendalikan Hama Paraeucosmetus sp. Pada Tanaman Padi Sawah di Kabupaten Minahasa Selatan (The Use of Endophytic Fungi Beauveria bassiana to Control Paraeucosmetus sp. on Rice Plant in South Minahasa District)
}

\author{
Susan S.C.A. Wowiling ${ }^{1 \star \star}$, J. Pelealu²) dan R.T.D. Maramis's) \\ 1)Balai Perlindungan Tanaman Pangan dan Hortikultura Provinsi Sulawesi \\ Utara \\ 2) Pascasarjana Universitas Sam Ratulangi, Manado Sulawesi Utara \\ *Email korespondensi: susan.wowiling@yahoo.co.id
}

Diterima 7 Agustus 2015, diterima untuk dipublikasikan 30 Agustus 2015

\begin{abstract}
Abstrak
Telah dilakukan penelitian yang bertujuan untuk mengetahui efektivitas penggunaan beberapa dosis Beauveria bassiana terhadap mortalitas hama Paraeucosmetus sp.. Penelitian ini menggunakan Rancangan Acak Kelompok (RAK) dengan empat perlakuan yang diulang empat kali. Perlakuan yang digunakan yaitu konsentrasi suspensi spora yang meliputi kontrol (tanpa suspensi spora cendawan), B. basiana dengan konsentrasi $10^{6} \mathrm{spora} / \mathrm{mL}$, B. basiana dengan konsentrasi $10^{8} \mathrm{spora} / \mathrm{mL}$, dan $B$. basiana dengan konsentrasi $10^{10} \mathrm{spora} / \mathrm{mL}$. Serangga uji adalah Paraeucosmetus sp. yang diambil dari pertanaman padi di lokasi penelitian. Jumlah serangga uji yang digunakan sebanyak 20 ekor untuk masing-masing perlakuan. Hasil penelitian menunjukkan bahwa aplikasi B. bassiana terhadap hama Paraeucosmetus sp. memperlihatkan serangga uji agak lambat bergerak dan selanjutnya mengalami kematian. Pada permukaan tubuh serangga uji yang mati terlihat adanya spora yang berwarna putih menyerupai kapas terutama pada pertemuan antara kepala dan toraks, segmen antena, femur, tibia, dan pada segmen abdomen. Hari kelima tubuh serangga uji mulai mengalami mummified atau sebagian tubuhnya ditumbuhi oleh miselium yang berwana putih. Mortalitas serangga uji yang tertinggi setelah aplikasi suspensi spora cendawan $B$. bassiana ditemukan pada perlakuan $10^{8}$ dengan tingkat mortalitas mencapai $100 \%$ pada hari kesembilan, diikuti dengan perlakuan $10^{10}$ mortalitas yang mencapai $100 \%$ pada hari ke-12, dan pada perlakuan $10^{6}$ tingkat mortalitas mencapai $100 \%$ pada hari ke-14. Pada kontrol belum ditemukan adanya serangga yang mati sampai pada pengamatan hari ke10. Pada perlakuan $10^{8}$ mortalitas terjadi pada hari ke-2 setelah aplikasi yakni mencapai 1,25\% dan pada hari ke-9 mortalitas serangga uji mencapai $100 \%$ serta tubuh serangga uji telah dipenuhi oleh miselium cendawan yang berwarna putih.

Kata kunci: Beauveria bassiana, padi, Paraeucosmetus sp.
\end{abstract}

\begin{abstract}
A study was conducted to determine the effectiveness of the use of multiple doses of Beauveria bassiana against pest mortality Paraeucosmetus sp. The research method used a randomized block design (RAK) with four treatments which were repeated four times. The treatment was the concentration of spore suspensions, i.e. control (no fungus spore suspension), B. basiana with a concentration of $10^{6}$ spores / $\mathrm{mL}$, B. basiana with a concentration of $10^{8}$ spores / $\mathrm{mL}$, and B. basiana with a concentration of $10^{10} \mathrm{spores} / \mathrm{mL}$. B. bassiana
\end{abstract}


application for controlling Paraeucosmetus sp. in rice plant showed that the insects began to move slowly, died, then spores started to invest the body, especially in the junction between the head and thorax, antennae segments, femur and tibia, and abdominal segments. On the fifth day, the insect's body began to mummify (part of insect's body was overgrown by mycelium which resembled white colored cotton). Observations on insect mortality after fungus application showed that the highest mortality was found in the treatment with $10^{8}$ of spore suspension with the test insect mortality rate reached $100 \%$ on the ninth day. The insect mortality reached $100 \%$ on the 12 th day in the treatment of $10^{10}$ spores $/ \mathrm{mL}$, and mortality reaches $100 \%$ on fourteenth day in the $10^{6}$ of spore suspension treatment. There was not any single dad insect found until the 10th day in control. One hundred percent mortality in each treatment showed that B. bassiana can effectively controlled Paraeucosmetus sp.

Keywords: Beauveria bassiana, Paraeucosmetus sp., rice

\section{PENDAHULUAN}

Paraeucosmetus sp. merupakan salah satu Organisme Pengganggu Tumbuhan (OPT) yang serangannya dapat menurunkan kualitas maupun kuantitas padi (Pelealu 1991, Watung 1996). Padi yang terserang akan mengakibatkan kualitas beras menjadi sangat rendah karena bila di makan akan terasa pahit. Penanganan OPT seharusnya memperhitungkan aspek ekologi agar tidak menimbulkan masalah lainnya yang lebih rumit di masa yang akan datang. Salah satu alternatif yang dapat dilakukan untuk penanganan OPT adalah dengan penerapan teknologi pengendalian yang ramah lingkungan. Beauveria bassiana adalah cendawan entomopatogen yang telah terbukti dapat dimanfaatkan sebagai agens hayati untuk mengendalikan berbagai jenis OPT. Penggunaan $B$. basiana aplikasinya aman bagi manusia dan tidak menimbulkan pencemaran terhadap lingkungan (Nankinga et al. 1996, Deacon 2005, Wagiman 2013).

Taroreh dan Pelealu (2011) mengemukakan bahwa Pareucosmetus sp. sudah ditemukan hampir pada semua areal pertanaman padi sawah di Minahasa dengan populasi dan serangan yang mengkhawatirkan. Hasil penelitian menunjukkan bahwa hama ini telah menyebar di daerah sentra produksi padi sawah termasuk Minahasa Selatan (Kaparang et al. 2013). Di Sulawesi Utara, pengendalian yang dilakukan oleh petani masih mengandalkan insektisida untuk serangga hama tersebut. Sedangkan pengendalian yang ramah lingkungan baru terbatas pada Leptocorixa acuta dengan pemanfaatan agens hayati Beauveria bassiana dan Metarhizium pada hama penting lainnya.Oleh sebab itu, perlu dilakukan penelitian pengendalian Paraeucosmetus sp. pada tanaman padi sawah dengan menggunakan agens hayati $B$. bassiana.

Penelitian bertujuan untuk mengetahui efektivitas penggunaan beberapa dosis $B$. bassiana terhadap mortalitas hama Paraeucosmetus sp.

\section{METODE}

Penelitian dilaksanakan di lahan sawah Desa Popontolen Kecamatan Tatapaan Kabupaten Minahasa Selatan Provinsi Sulawesi Utara sejak bulan Agustus 2013 sampai bulan Januari $2014 . \quad$ Perbanyakan Beauveria bassiana menggunakan Laboratorium Agens Hayati Balai Perlindungan Tanaman Pangan dan Hortikultura Provinsi Sulawesi Utara. 
Metode penelitian menggunakan Rancangan Acak Kelompok (RAK) dengan empat perlakuan yang diulang sebanyak empat kali. Adapun perlakuan yang digunakan adalah konsentrasi suspensi spora, yaitu kontrol (tanpa suspensi spora cendawan), $B$. basiana dengan konsentrasi $10^{6}$ spora $/ \mathrm{mL}$, B. basiana dengan konsentrasi $10^{8} \mathrm{spora} / \mathrm{mL}$, dan $B$. basiana dengan konsentrasi $10^{10} \mathrm{spora} / \mathrm{mL}$.

\section{Perbanyakan B. bassiana}

Media beras dicuci bersih dan direndan dalam aquades selama lebih kurang 24 jam, ditiriskan kemudian dikeringanginkan. Beras yang telah kering dimasukkan dalam kantongkantong plastic masing-masing sebanyak $100 \mathrm{~g} / \mathrm{kantong}$ lalu disterilkan menggunakan autoclave. $B$. bassiana sebagai starter diinokulasikan atau ditumbuhkan di dalam media beras steril yang telah dingin. Inokulasi dilakukan di dalam ent-kas untuk menghindari terjadinya kontaminasi. Masing-masing kantong platik berisi $\mathrm{B}$. bassiana yang telah diisolasi diberi label sesuai tanggal perbanyakan, media dan diletakkan pada wadah atau rak yang bersih.

\section{Penghitungan Konsentrasi Spora}

Penghitungan konsentrasi spora dilakukan pada hasil isolat padat dengan menggunakan heuemacytometer. Apabila telah mendapatkan konsentrasi spora $10^{6} / \mathrm{mL}$ pada media beras, media tersebut dipisahkan. Penghitungan selanjutnya dilakukan pada media berikutnya, apabila telah mendapatkan konsentrasi spora $10^{8} / \mathrm{mL}$ media tersebut diambil dan disendirikan; dilanjutkan dengan media yang lain untuk mendapatkan konsentrasi spora $10^{10} / \mathrm{mL}$.

Aplikasi perlakuan/penyemprotan

Aplikasi suspensi B. Bassiana dilaku-kan pada kondisi lapangan. Masing-masing perlakuan disemprotkan pada serangga uji yang berada dalam kurungan kelambu. Kurungan kelambu berukuran $60 \mathrm{~cm} x$ $60 \mathrm{~cm} \times 120 \mathrm{~cm}$ dan terbuat dari rangka belahan bambu dan ditutupi dengan kain kasa halus yang pada salah satu sisinya diberi rets/uiting agar dapat dibuka dan ditutup bila dilakukan aplikasi dan pengamatan.

Serangga uji adalah imago Paraeucosmetus sp. yang diperoleh dari areal pertanaman padi yang ada disekitar lokasi penelitian. Jumlah serangga uji pada masing-masing kurungan kotak kelambu adalah sebanyak 20 ekor. Penyemprotan suspensi spora cendawan menggunakan handsprayer dan dilakukan pada sore hari.

\section{Pengamatan perilaku serangga uji setelah aplikasi}

Pengamatan perilaku serangga uji dilakukan sehari setelah penyemprotan suspense spora $B$. bassiana. Serangga uji diamati setiap hari sampai serangga mati. Adanya perubahan-perubahan perilaku dan gejala serangan $B$. bassiana pada serangga uji diamati dan dicatat setiap hari.

\section{Persentase mortalitas serangga uji setelah aplikasi}

Pengamatan

mortalitas dilakukan dengan mengamati serangga uji. Serangga yang mati diambil dan dihitung. Untuk mengetahui persentase mortalitas serangga uji digunakan rumus sebagai berikut: \% mortalitas = (Jumlah serangga yang mati/jumlah serangga uji yang diamati) x $100 \%$.

\section{Analisis Data}

Data yang diperoleh dianalisis dengan Analisis Sidik Ragam dan kemudian dilanjutkan dengan uji BNJ (Bukti Nyata Jujur) 5\% untuk melihat adanya perbedaan antar perlakuan.

\section{HASIL DAN PEMBAHASAN}

Hasil penelitian menunjukkan bahwa aplikasi $B$. bassiana terhadap hama Paraeucosmetus sp. pada 
tanaman padi, menunjukkan gejala serangga uji mulai terlihat agak lambat bergerak (Gambar 1a) dan pada hari kedua mengalamikematian. Pada permukaan tubuh hama mulai terlihat adanya miselium yang berwarna putih menyerupai kapas terutama pada pertemuan antara kepala dan toraks, segmenantena, femur, tibia, dan pada segmen abdomen (Gambar 1b), pada hari kelima tubuh serangga uji mulai mengalami mummified atau sebagian tubuh serangga uji telah ditumbuhi oleh miselium yang berwana putih menyerupai kapas (Gambar 1c).

Gejala tersebut sama seperti yang sampaikan oleh Steinhaus (1967) dalam Patahuddin (2005) bahwa gejala awal dari infeksi oleh cendawan $B$. bassiana adalah serangga tidak makan, gerakan menjadi lemah, bergerak tidak menentu. Sama seperti penelitian Patahuddin (2005) larva Spodoptera exigua yang terinfeksi menunjukkan penurunan gerak atau malas bergerak walaupun telah disentuh dan berkurangnya kemauan makan.
Steinhaus (1967) menyatakan bahwa waktu yang dibutuhkan untuk menyebabkan kematian inang ditentukan oleh berbagai faktor, diantaranya virulensi patogen, sifat resistensi inang serta kondisi lingkungan yang membantu infeksi dan pertumbuhan pathogen. Mc. Inns (1975) dalam Santoso (1993) menyatakan bahwa terdapat empat tahap etiologi penyakit cendawan pada serangga. Pertama, kontak antara propagul cendawan dengan serangga. Senyawa mukopolisakarida berperan penting dalam proses kontak antara cendawan dan serangga. Kedua, penempelan dan perkecambahan propagul cendawan pada integument serangga. Kelembaban udara tinggi, bahkan kadang-kadang air diperlukan untuk perkecambahan propagul cendawan. Cendawan dapat memanfaatkan senyawa-senyawa yang terdapat pada integmen.

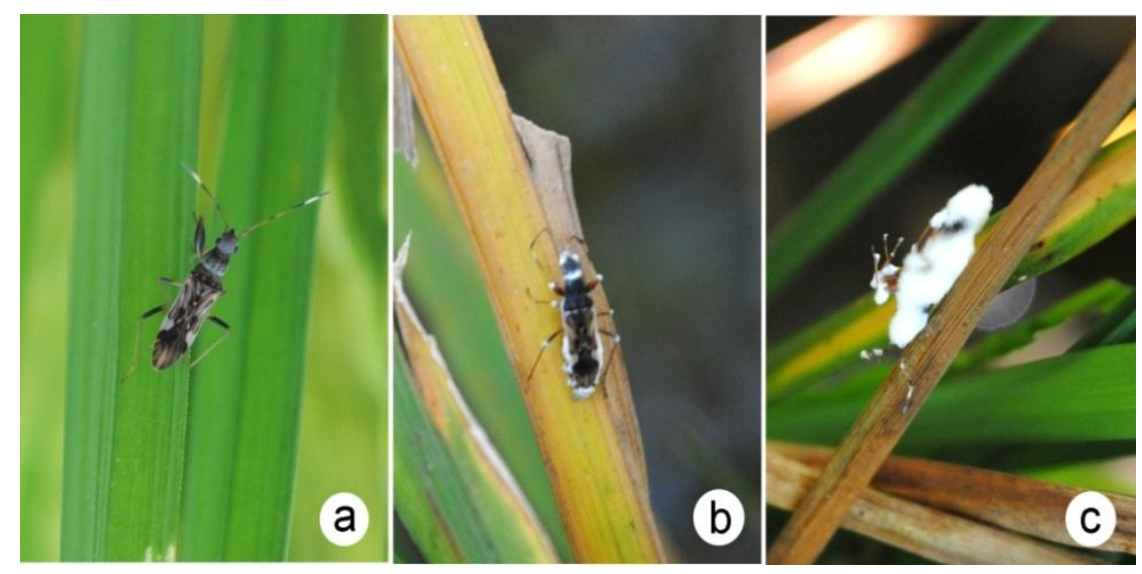

Gambar 1. Gejala serangan B. bassiana pada Paraeucosmetus sp.

a. Gerakan menjadi lemah/malas bergerak

b. Tubuh mulai ditumbuhi spora yang berwarna putih

c. Seluruh tubuh dipenuhi oleh spora cendawan yang berwana putih 
Integumen serangga mengandung senyawa yang dapat berfungsi sebagai stimulant bagi cendawan, sedangkan senyawa pada kutikula serangga merupakan inhibitor bagi perkembangan cendawan $B$. bassiana, Ketiga, tahap penetrasi dan invasi. Dalam melakukan penetrasi menembus integument, cendawan membentuk tabung kecambah. Dalam hal ini titik penetrasi sangat dipengaruhi oleh konfigurasi morfologi integumen. Cendawan juga membentuk appresorium untuk menembus integumen. Penembusan dilakukan secara mekanis dan/atau secara kimiawi dengan mengeluarkan enzim atau toksin. Keempat, tahap destruksi, yaitu terbentuk blastospora di dekat dengan titik penetrasi yang kemudian beredar dalam hemolimfa dengan membentuk hifa sekunder untuk menyerang jaringan lain. Pada umumnya seranga sudah mati sebelum proliferasi blastospora. Perkembangan cendawan dapat lambat atau sangat ekstensif. Setelah serangga mati fase perkembangan saprofit dimulai dengan menyerang jaringan dan berakhir dengan pembentukan organ reproduksi. Pada umumnya semua jaringan serangga dapat diserang. Serangga mati dengan tubuh yang mengeras seperti mumi, karena terjadi kolonisasi oleh cendawan di dalam tubuh serangga dan cairan tubuh serangga segera habis digunakan oleh cendawan.

Pengamatan terhadap mortalitas serangga uji setelah aplikasi penyemprotan suspensi spora cendawan $B$. bassiana ternyata tertinggi ditemukan pada perlakuan $10^{8}$ dengan tingkat mortalitas serangga uji mencapai $100 \%$ pada hari ke sembilan, kemudian pada perlakuan $10^{10}$ mortalitas mencapai $100 \%$ pada hari ke-12, dan pada perlakuan $10^{6}$ mortalitas mencapai $100 \%$ pada hari ke-14. Sedangkan pada kontrol sampai pada pengamatan hari ke 10 belum ditemukan adanya serangga yang mati, selengkapnya dapat dilihat pada Tabel 1. Pada perlakuan $10^{8}$ mortalitas ditemukan pada hari ke-2 setelah aplikasi yakni mencapai 1,25\% dan pada hari ke-9 mortalitas serangga uji telah mencapai $100 \%$ serta tubuh serangga uji telah dipenuhi oleh spora cendawan yang berwarna putih. Pencapaian mortalitas sebesar $100 \%$ pada masing-masing perla-kuan menunjukkan efektivitas cendawan $B$. bassiana dalam mengendalikan hama Paraeucosmetus sp.

Tanada dan Kaya (1993) menyatakan bahwa virulensi spora cendawan entomo-patogen sangat ditentukan oleh jumlah dan umur spora. Nankinga et al. (1996) pada tahap destruksi dan kolonisasi, menginfeksi saluran pencernaan dan sistem pernafasan. Proses-proses tersebut umumnya berlang-sung antara 1-2 hari tergantung jenis cendawan dan kondisi lingkungan. Lebih lanjut Novizan (2002) menyatakan bahwa setelah berhasil melakukan penetrasi dan masuk ke dalam tubuh serangga, cendawan akan mengeluarkan toksin Beauvericin mengakibatkan kerusakan jaringan tubuh serangga dan pada dua hari kemudian serangga akan mengalami kematian yang disertai dengan tumbuhnya spora cendawan pada permukaan tubuh serangga. Pada serangan lanjut tubuh serangga akan mengalami "mummified" atau tubuh menjadi keras dan kaku serta ditumbuhi oleh spora cendawan yang berwarna putih. Keefektifan cendawan entomopatogenik sangat tergantung pada jenis isolate, kerapatan sprora, kualitas media tumbuh, jenis dan umur serangga inang, waktu aplikasi dan faktor lingkungan diantaranya sinar matahari (ultra violet) curah hujan dan kelembaban (Widayar dan Rayati 1993, Julianto 2000). Tanada dan 
Tabel 1. Persentase mortalitas Paraeucosmetus sp. pada berbagai konsentrasi spora cendawan

\begin{tabular}{|c|c|c|c|c|}
\hline \multirow[t]{2}{*}{$\begin{array}{c}\text { Pengamatan } \\
\text { Hari ke ... } \\
\text { (Setelah aplikasi) }\end{array}$} & \multicolumn{4}{|c|}{$\begin{array}{l}\text { Persentase mortalitas serangga uji pada masing } \\
\text { masing perlakuan dosis (per } 80 \text { ekor) }\end{array}$} \\
\hline & $10^{6}$ & $10^{8}$ & $10^{10}$ & Kontrol \\
\hline 1 & 0 & 0 & 0 & 0 \\
\hline 2 & 0 & 1,25 & 0 & 0 \\
\hline 3 & 0 & 11,25 & 0 & 0 \\
\hline 4 & 5,0 & 36,25 & 3,75 & 0 \\
\hline 5 & 10,0 & 53,75 & 18,75 & 0 \\
\hline 6 & 17,5 & 77,50 & 28,75 & 0 \\
\hline 7 & 25,0 & 92,50 & 46,25 & 0 \\
\hline 8 & 35,0 & 98,75 & 61,25 & 0 \\
\hline 9 & 48,75 & 100 & 71,25 & 0 \\
\hline 10 & 63,75 & - & 83,75 & 0 \\
\hline 11 & 75,76 & - & 95,00 & 0 \\
\hline 12 & 91,25 & - & 100 & 0 \\
\hline 13 & 98,75 & - & - & 0 \\
\hline 14 & 100 & - & - & 0 \\
\hline
\end{tabular}

Kaya (1993) mengemukakan bahwa temperatur optimum umtuk perkembangan patogenisitas dan daya tahan hidup cendawan berkisar antara 20-30 ${ }^{\circ} \mathrm{C}$ dan di atas $30{ }^{\circ} \mathrm{C}$ akan memberikan efek yang merugikan bagi cendawan entomopatogen.

Berdasarkan hasil Analisis Sidik Ragam menunjukkan bahwa penggunaan cendawan $B$. bassiana berpengaruh terhadap mortalitas hama Parauecosmetus sp. pada tanaman padi, sehingga dilanjutkan dengan Analisis Beda Nyata Jujur (Tabel 2). Berdasarkan hasil uji Beda Nyata Jujur penggunaan cendawan $B$. bassiana terhadap mortalitas hama Parauecosmetus sp. pada tanaman padi menunjukkan bahwa pada tiga hari setelah aplikasi perlakuan kontrol, $10^{6}$, dan $10^{10}$ tidak menunjukkan adanya perbedaan. Penggunaan cendawan $B$. bassiana terhadap mortalitas hama Parauecosmetus sp. pada tanaman padi pada kontrol, perlakuan $10^{6}$ dan $10^{10}$ berbeda dengan perlakuan $10^{8}$. Hal ini disebabkan oleh jumlah spora yang efektif untuk membunuh hama Paraeucosmetus sp. seperti pada perlakuan $10^{8}$, sedangkan yang perlakuan $10^{10}$ jumlah spora banyak tetapi daya racun sudah berkurang. Pada pengamatan hari keempat setelah aplikasi, polanya sama dengan hasil pada pengamatan tiga hari setelah aplikasi.

Hasil pengamatan Analisis Beda Nyata Jujur penggunaan cendawan $B$. bassiana terhadap mortalitas hama Parauecosmetus sp. pada pengamatan hari ke-5, ke-6, ke-7 dan ke-8 polanya sama. 
Perlakuan Kontrol berbeda dengan $10^{6}, 10^{10}$, dan $10^{8}$, kemudian perlakuan $10^{6}$ berbeda dengan $10^{10}$ dan $10^{10}$ berbeda dengan $10^{8}$. Pengamatan pada hari ke-9, menunjukkan bahwa mortalitas hama Paraeucosmetus sp telah mencapai $100 \%$ pada perlakuan $10^{8}$, kemudian pengamatan pada hari ke-12 setelah aplikasi untuk perlakuan $10^{10}$ mortalitas hama Paraeucosmetus sp mencapai $100 \%$ dan pengamatan pada hari ke- 13, mortalitas hama Paraeucosmetus sp. mencapai 100\% pada perlakuan $10^{6}$.

\section{KESIMPULAN}

Hama Paraeucosmetus sp. yang terinfeksi cendawan Beauveria bassiana, pada hari pertama menunjukkan perilaku bergerak agak lambat, hari ke-2 mengalami kematian, hari ke-2 terlihat adanya spora yang berwarna putih menyerupai kapas pada tubuh serangga, diantara kepala dan toraks, segmen antena, femur dan tibia, dan pada segmen abdomen. Pada hari kelima, sebagian besar tubuh hama telah ditumbuhi oleh spora. Mortalitas tertinggi hama Paraeucosmetus sp. setelah aplikasi cendawan $B$. bassiana terdapat pada perlakuan B2, yaitu mencapai $100 \%$ pada hari ke- 9 , kemudian pada perlakuan B1 mencapai $100 \%$ pada hari-14, dan perlakuan B3 mencapai 100\% mortalitas pada hari ke-12 dan pada kontrol tidak ditemukan adanya mortalitas pada serangga uji.

\section{DAFTAR PUSTAKA}

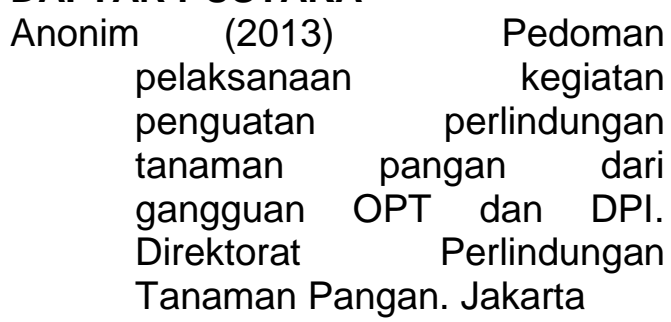
Julianto YD (2000) Penggunaan Beauveria bassiana untuk pengendalian hama tanaman kopi dan kakao. Workshop nasional Pengendalian Hayati OPT Tanaman Perkebunan di Cipayung 15-17 Februari 2000

Patahuddin (2005) Uji beberapa konsentrasi dan resistensi Beauveria bassiana Vullemin (Deteromicetes: Monilicciceae) terhadap mortalitas Spodoptera exigua Hubner (Lepidoptera: Nuctuidae) pada tanaman bawang merah. Prosiding Seminar IImiah dan Pertemuan Tahunan PEI dan PFI XVI Komda Sulsel, 2005

Pelealu J (1991) Bionomi Paraeucosmetus sp. (Hemiptera: Lygaeidae) pada tanaman padi. Tesis Fakultas Pascasarjana Institus Pertanian Bogor

Santoso T (1993) Prospek pengembangan Beauveria bassiana sebagai agens hayati. Dasar-dasar patologi serangga. Prosiding Makalah Simposium Patologi Serangga I, Yogyakarta, 12-13 Oktober 1993. pp 1-15

Steinhaus EA (1967) Principles of insect pathology. Mac Graw Hill Book, Co. Inc, New York

Tanada Y, Kaya HK (1993) Insect pathology. Academic Press Inc, New York

Widayar W, Rayati DJ (1993) Pengaruh frekuensi penyemprotan jamur entomopatogenik terhadap ulat jengkal (Ectroposblurmitra) di Perke-bunan Teh. Simposium Patologi Serangga I. Yogyakarta, 12 - 13 Oktober 2013

Wagiman (2013) Meningkatnya peran agen hayati dalam pengelolaan ekosistem secara kuantitatif. Jurusan Hama dan Penyakit Tumbuhan, Fakultas Pertanian UGM. Jl. Flora, Bulaksumur, Yogyakarta

Watung FW (1996) Morfologi dan biologi Paraeucosmetus sp. (Hemiptera: Lygaeidea) yang 
62 JURNAL BIOSLOGOS, AGUSTUS 2015, VOL. 5 NOMOR 2

hidup pada tanaman padi dan rumput Paspalum (Paspalum conjugatum Berg). Tesis Fakultas Pascasarjana Institut Pertanian Bogor

Yahya HB (2012) Paraeucosmetus pallicornis Dallas (Kepik

Hitam). http://info hama penyakit tumbuhan.blogspot.co.id/2012/paraeu cosmetus-pallicornis-dallaskepik

Tabel 2. Rata-rata Hasil Analisis Beda Nyata Jujur penggunaan cendawan $B$. bassianaterhadap mortalitas hama Parauecosmetus sp. pada tanaman padi

\begin{tabular}{|c|c|c|c|c|c|c|c|c|c|c|c|}
\hline \multirow{2}{*}{ Perlakuan } & \multicolumn{11}{|c|}{ Mortalitas (\%) } \\
\hline & 3 hsa & 4 has & 5 hsa & 6 hsa & 7 hsa & 8 hsa & 9 hsa & 10 hsa & 11 hsa & 12 hsa & 13 has \\
\hline Kontrol & $0,00 \mathrm{a}$ & $0,00 a$ & $0,00 a$ & $0,00 \mathrm{a}$ & $0,00 a$ & $0,00 \mathrm{a}$ & 0,00 & $0,00 a$ & $0,00 a$ & $0,00 a$ & 0,00 \\
\hline$A\left(10^{6}\right)$ & $0,00 a$ & $5,00 a$ & $10,00 b$ & $16,67 b$ & $26,67 b$ & $36,67 b$ & 51,67 & $65,00 b$ & $80,00 a b$ & $93,33 b$ & 100,00 \\
\hline B $\left(10^{8}\right)$ & $11,67 b$ & $36,67 b$ & $55,00 d$ & $76,67 d$ & $91,67 d$ & $98,33 d$ & 100,00 & $0,00 a$ & $0,00 a$ & $0,00 a$ & 0,00 \\
\hline$C\left(10^{10}\right)$ & $0,00 a$ & $3,33 a$ & $18,33 c$ & $28,33 c$ & $46,67 c$ & $61,67 c$ & 71,67 & $85,00 c$ & $96,67 b$ & $100,00 b$ & 0,00 \\
\hline BNJ 5\% & 4,22 & 8,43 & 7,60 & 10,75 & 13,17 & 11,36 & & 19,33 & 18,74 & 86,84 & \\
\hline
\end{tabular}

Keterangan : *) Angka yang diikuti huruf yang sama pada kolom yang sama tidak berbeda nyata pada uji BNJ $5 \%$, hsa $=$ hari setelah aplikasi 
